\title{
A new species from Genus Megachile Subgenus Callomegachile (Hymenoptera, Megachilidae) from Chandigarh and Punjab plains
}

\author{
Priyanka Kumari* and Neelima R. Kumar \\ Department of Zoology, Panjab University, Chandigarh-160014, INDIA \\ *Corresponding author. E-mail: priyanka.dadhwal.chandel@gmail.com \\ Received: November 14, 2017; Revised received: December 20, 2017; Accepted: February 20, 2018
}

\begin{abstract}
A new species Megachile pseudodisjuncta of the bee is being reported from Genus Megachile and Subgenus Callomegachile. It bears a close resemblance to $M$. disjuncta from which it has been distinguished on the basis of certain morphological characters and genitalia. Megachilid bees bear utmost significance because they are very good pollinators of both cultivated and wild fauna. Consequently, their taxonomic identification and conservation are very crucial. The detailed taxonomically important morphological characters of both the species were studied and photographed. Male sternum and genitalia were studied microscopically and photographed. The material examined and floral associations have also been presented in the paper.
\end{abstract}

Keywords: Morphometric measurements, Male genitalia, Sternum 5, Sternum 8, Floral associations

\section{INTRODUCTION}

Tribe Megachilini pertains to long-tongued family Megachilidae. The tribe Megachilini consists of the true 'leaf cutter bees' except some resin users and cleptoparasites. Distinguishing feature of this tribe is the absence of arolia, the presence of two submarginal cells, jugal lobe shorter than vannal lobe. In India, around 75 species were reported by Gupta (1999).

Females- bevelled cutting edges present on mandibles in between teeth, metasoma cordate, scopal hairs present throughout sterna 2-6, metatarsi of hind leg modified into broad or flattened shapes.

Males- bevelled cutting edges absent, metasoma parallel sided, tergum 6 is more distinct with concave dentate margin, tergum 7 is hidden beneath it, and hence the number of terga remaining visible ranges from 4-6. They are mostly solitary bees whose females carry pollen under their abdomen in scopae. Both the bee species Megachile disjuncta (Fabricius) and Megachile pseudodisjuncta $\mathrm{sp}$. n. discussed here comes under Subgenus Callomegachile Michener are known to be gregarious (personal observation). The females of both the above said species construct their individual nests near to each other but carry out their maternal duties individually without the help of others. As a result, while foraging on flowers, they can be seen in a bunch. Males come out of eggs before females, flies for some time, mates with the females emerging later out of eggs and then finally dies. Michener in 2000 updated the classification of Megachilini and placed all nonparasitic Megachilini under genus Megachile.

\section{MATERIALS AND METHODS}

Specimens of Subgenus Callomegachile Michener were collected from Chandigarh (U.T.) $30^{\circ} 44^{\prime}$ 29.3352" N, 76 46' 5.0376" E, Panchkula (Haryana) $30^{\circ} 41^{\prime} 42.7272 " \mathrm{~N}, 76^{\circ} 51^{\prime} 15.0192 " \mathrm{E}$, Ludhiana (Punjab) 30 54' 3.4740" N 75 51' 26.1972" E, Kurukshetra (Haryana) ,N "10.2468 '58 ${ }^{\circ} 29 \quad 52{ }^{\circ} 76$ ,E "41.8116Hoshiarpur (Punjab) 31 $31^{\circ}$ ' 38.4780" N, $75^{\circ} 54^{\prime} 49.2228^{\prime \prime} \mathrm{E}$ and Jalandhar (Punjab) $31^{\circ} 19^{\prime}$ 33.6540" N, 75 34' 34.2480" E from March 2013 to April 2015. Collection nets were used for collection during foraging hours of the bees. They were mostly collected from 8 am to $4 \mathrm{pm}$ during day time in summers as their activity was maximum during these hours. After killing the specimen with ethyl acetate vapours, they were properly stretched, preserved and identified. Keys for Oriental fauna given by Bingham (1897), Gupta (1999) and Michener (1962, 2000, 2007) were used for identification. Adults were photographed with Canon D60 digital camera, and the morphometric measurements were carried out with stereo zoom microscope with RSM 9 software fitted with a Jenoptic camera. Male genitalia slides and sternum were prepared and photographed with Leica microscope.

\section{RESULTS}

Megachile (Callomegachile) pseudomegachile sp. novo

Female (Plate III, Figs. a-e)

Diagnosis: Pubescence on the paraocular area, hypo- 
Priyanka Kumari and Neelima R. Kumar / J. Appl. \& Nat. Sci. 10 (1): 454 - 458 (2018)

Table 1. Measurements (mm) of species - M. disjuncta and M. pseudodisjuncta.

\begin{tabular}{|c|c|c|c|c|}
\hline \multirow{2}{*}{ Characters } & \multicolumn{2}{|c|}{ M. disjuncta } & \multicolumn{2}{|c|}{ M. pseudodisjuncta } \\
\hline & o & $\hat{0}$ & o & $0^{1}$ \\
\hline Body length & 15.1 & 12.7 & 14.83 & 10.97 \\
\hline Head width & 4.44 & 3.61 & 4.88 & 3.98 \\
\hline Head length & 3.40 & 2.89 & 3.64 & 3.11 \\
\hline Interantennal distance & 1.19 & 1.14 & 1.21 & 1.19 \\
\hline Antennocular distance & 1.46 & 1.25 & 1.97 & 1.21 \\
\hline Distance from anterior ocellus to antennal socket & 1.39 & 1.13 & 1.52 & 1.05 \\
\hline Distance between upper inner margins of compound eyes & 2.48 & 2.46 & 3.10 & 2.25 \\
\hline Distance between lower margins of compound eyes & 2.94 & 2.24 & 2.86 & 2.56 \\
\hline Width of vertex & 2.49 & 1.96 & 2.38 & 1.22 \\
\hline \multirow[t]{2}{*}{ Clypeus basal \& apical width } & 1.18 & 0.98 & 0.93 & 1.21, \\
\hline & 2.06 & 1.11 & 1.73 & 1.54 \\
\hline Clypeus median 1 & 0.88 & 0.72 & 1.59 & 1.04 \\
\hline Length of labrum & 0.78 & 0.44 & 1.99 & 1.45 \\
\hline Width of labrum & & 2.30 & 2.18 & 2.08 \\
\hline Malar space & 0.54 & 0.21 & 0.19 & .08 \\
\hline Length of mandible & 2.04 & 1.35 & 1.82 & 1.56 \\
\hline \multirow[t]{12}{*}{ Relative length of scape, pedicel and segments of antennae } & 0.98 & 0.51 & 0.79 & 0.50 \\
\hline & 0.33 & 0.20 & 0.23 & 0.81, \\
\hline & 0.12 & 0.34 & 0.24 & 0.29 \\
\hline & 0.22 & 0.41 & 0.28 & 0.38 \\
\hline & 0.31 , & 0.38 & 0.34 & 0.38 \\
\hline & 0.31 , & 0.36 & 0.32 & 0.37, \\
\hline & 0.28 & 0.41 & 0.30 & 0.40 \\
\hline & 0.28 & 0.37 & 0.29 & 0.37, \\
\hline & 0.29 & 0.39 & 0.36 & 0.41, \\
\hline & 0.31 , & 0.34 & 0.35 & 0.37 \\
\hline & 0.25 , & 0.35 & 0.34 & 0.30 \\
\hline & 0.38 & 0.33 & 0.41 & 0.43 \\
\hline \multirow[t]{2}{*}{ Width of segment vi \& $\mathrm{x} / \mathrm{xi}$} & 0.25 , & 0.19 & 0.23 & 0.20 \\
\hline & 0.24 & 0.16 & 0.16 & 0.12 \\
\hline Length of jugal lobe & 2.02 & 2.00 & 3.74 & 2.36 \\
\hline Length of vanal lobe & 4.75 & 3.52 & 1.48 & 1.79 \\
\hline Total length of hind wing & 8.06 & 6.33 & 7.03 & 5.88 \\
\hline Marginal cell length & 2.58 & 2.21 & 2.09 & 1.82 \\
\hline Stigma cell length & 1.07 & 0.77 & 0.70 & 0.74 \\
\hline Total length of fore wing & 10.2 & 8.18 & 9.01 & 6.86 \\
\hline Median length of scutum & 3.10 & 1.88 & 2.86 & 2.00 \\
\hline Maximum width of scutum & 4.66 & 2.88 & 3.82 & 3.19 \\
\hline Median length of scutellum & 1.12 & 1.12 & 0.75 & 1.08 \\
\hline \multirow[t]{6}{*}{ Relative width of terga $1-6$} & 4.58 & 2.85 & 4.55 & 2.98 \\
\hline & 4.83 & 3.21 , & 4.51, & 3.23 \\
\hline & 4.83, & 3.21, & 4.39 & 3.17, \\
\hline & 4.55, & 2.94, & 4.08 & 3.01, \\
\hline & 3.87, & 2.36, & 3.40 & 2.59 \\
\hline & 2.07 & 1.11 & 1.88 & 1.96 \\
\hline Length of mesosoma & 4.30 & 2.93 & 4.84 & 3.40 \\
\hline Length of metasoma & 7.18 & 5.50 & 6.62 & 5.13 \\
\hline Length of coxa & 1.15 & 0.81 & 0.84 & 0.69 \\
\hline Length of trochanter & 0.65 & 0.38 & 0.41 & 0.63 \\
\hline Length of femur & 1.16 & 1.38 & 1.56 & 1.61 \\
\hline Length of tibia & 2.86 & 1.80 & 1.81 & 1.24 \\
\hline Length of basitarsus & 1.75 & 1.07 & 2.30 & 0.71 \\
\hline Length of distitarsus & 0.60 & 0.61 & 0.71 & 0.72 \\
\hline
\end{tabular}

stome, thorax black, vertex dark greyish, basal margin of scutellum , apical margin of $1^{\text {st }}$ tergum with bright white pubescence, rest terga black, scopae in sternum and tarsi with fulvous red.

Head: Declivous clypeus, diagonally even, supra clypeus bulged in a triangular form, an ocellar area carved, hypostome smooth and perforated, fringed labrum margins, mandibles narrow, looped, tridentate, genae wide.

Mesosoma: Scutum convex, streaked with parapsidal lines, swollen pronotal lobes, scutellum curved, continuous with midline of scutum, first recurrent vein far 
Priyanka Kumari and Neelima R. Kumar / J. Appl. \& Nat. Sci. 10 (1): 454 - 458 (2018)

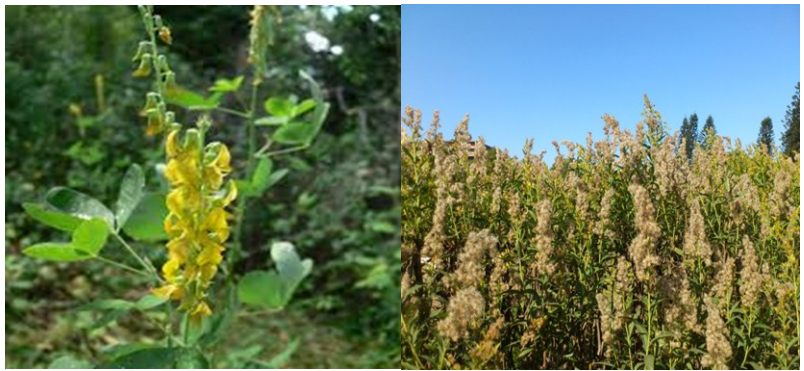

Fig. 1a. Cajanus pallida (L.) 1b. Crotalaria juncea (L.)

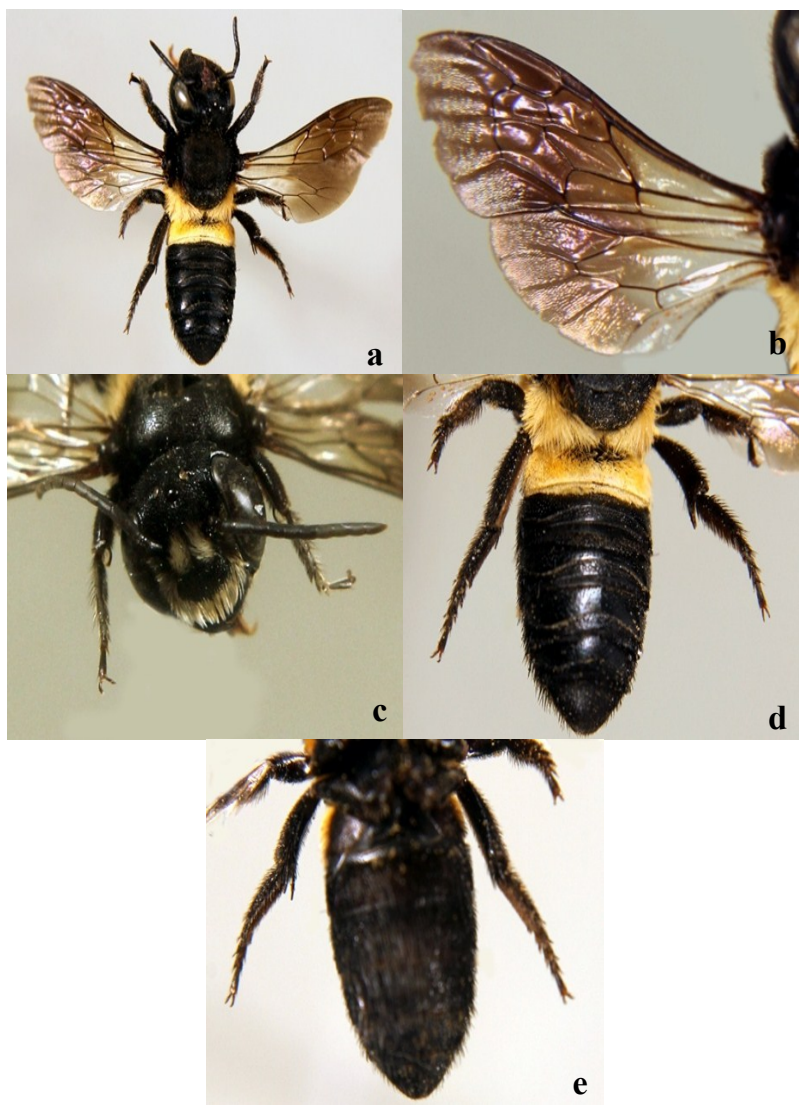

Plate I (Figs. a-e) Megachile disjuncta (Fabricius) female (a.) Habitus, dorsal view (b.) Wings (c.) Head and Mesosoma, dorsal view (d.) Metasoma, dorsal view (e.) Sterna (Scopae), ventral view.

from base than second, wings hyaline at bottom becoming yellowish chromatic at the tips, differentiating it from M. disjuncta in which it becomes blackish chromatic, forelegs simple with apico-dorsally pointed short spine, fringed tarsus, mid and hind legs mostly unadapted, simple tarsi with basitarsus and distitarsus.

Metasoma: Incarinate tergum, pregrandular area punctate and glowing, wide postgrandular area, bulging, convex and punctate, tergum 1-6 wide, convex and granulated, punctures coarse, dense and granulated, tergum 6 declivous, sternal hairs present on 2-5 sterna, scopal hairs fulvous, sternum $6^{\text {th }}$ protuberant, rounded marginally.

Male (Plate IV, Figs. a-g)

Diagnosis: Pubescence black on face, hypostome, and

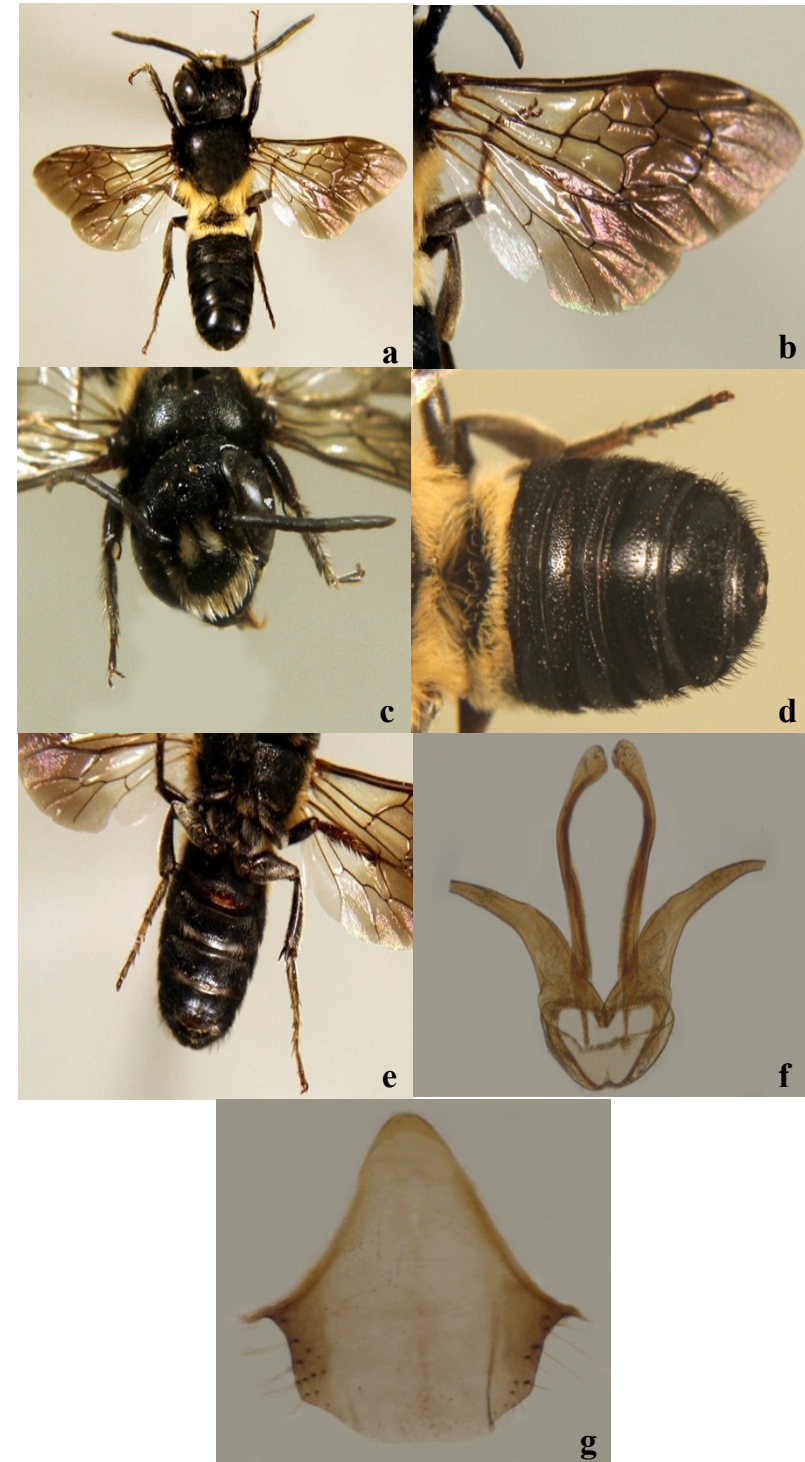

Plate II (Figs. a-g): Megachile disjuncta (Fabricius) male (a.) Habitus, dorsal view (b.) Wings (c.) Head and Mesosoma, dorsal view (d.) Metasoma, dorsal view (e.) Sterna , ventral view (f.) Genitalia (g.) Sternum 8.

vertex, apical marginal fasciae of $1^{\text {st }}$ tergum yellow, dorsal side of tibiae and tarsus fulvous, the base of claws and apical sternites golden.

Head: Clypeus in males like a female, cambered, curved, punctate with notched tip apically, tridentate mandible, pubescent with white hairs; supraclypeus raised with outcurved apical margin, punctate, pubescent; vertex punctured coarsely and flat.

Mesosoma: Scutum black, convex, punctured finely, shining; scutellum with straight apical margin and rounded basal margin, covered densely with white hairs; acute apical tooth, short and needle like spine on tibiae directed apically, punctures close, dense, unmodified mid leg and hind leg,

Metasoma: Tergum $6^{\text {th }}$ gradulus complete and carinate, $7^{\text {th }}$ tergum wider than long, rounded, stiffened, 


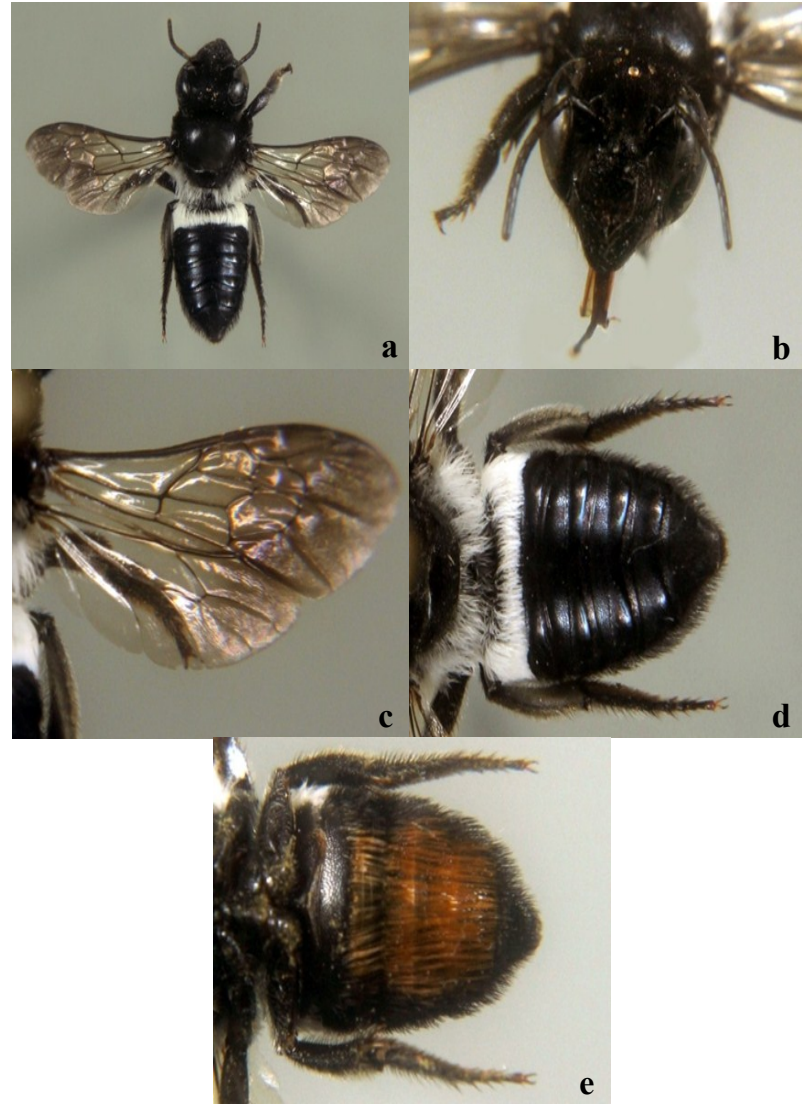

Plate III (Figs. a-e): Megachile pseudodisjuncta sp. $n$. female (a.) Habitus, dorsal view (b.) Head and Mesosoma, dorsal view (c.) Wing (d.). Metasoma, dorsal view (e.) Ster$n a$, ventral view.

coagulated at the apex, sterna also thick and declivous to the margins.

External genitalia: Gonocoxites are thin and narrow from the base along the length to be a little rounded at the tip to form gonostylus. Penis valves are thin and incurved at tips.

Etymology: This species is closely related to $M$. disjuncta (Plate I, Figs. a-e and Plate II, Figs. a-g) (Kumari and Kumar, 2014) but the two species differ in many notable characters, e.g. pubescence. White down present in both sexes of M. pseudodisjuncta sp. n. (Plate III, Fig. a-b and Plate IV, Fig. a-b) in place of yellow pubescence prevalent in $M$. disjuncta (Plate I, Fig. a-b and Plate II, Fig. a-b ). The abdomen of female M. pseudodisjuncta sp. n. (Plate III, Fig. d) wider and shorter than $M$. disjuncta (Plate I, Fig. d). Scopal hairs fulvous brown in case of $M$. pseudodisjuncta (Plate III, Fig. e) which are black in M. disjuncta (Plate I, Fig. e). M. pseudodisjuncta is slightly shorter than M. disjuncta (Table-1). All the measurements of length and width of various body parts of $M$. pseudodisjuncta are comparatively less than $M$. disjuncta.

Structure of male genitalia differs a lot in the two species. Gonocoxite is thin, narrow from base to apex in M. pseudodisjuncta (Plate IV, Fig. f). Whereas in $M$.

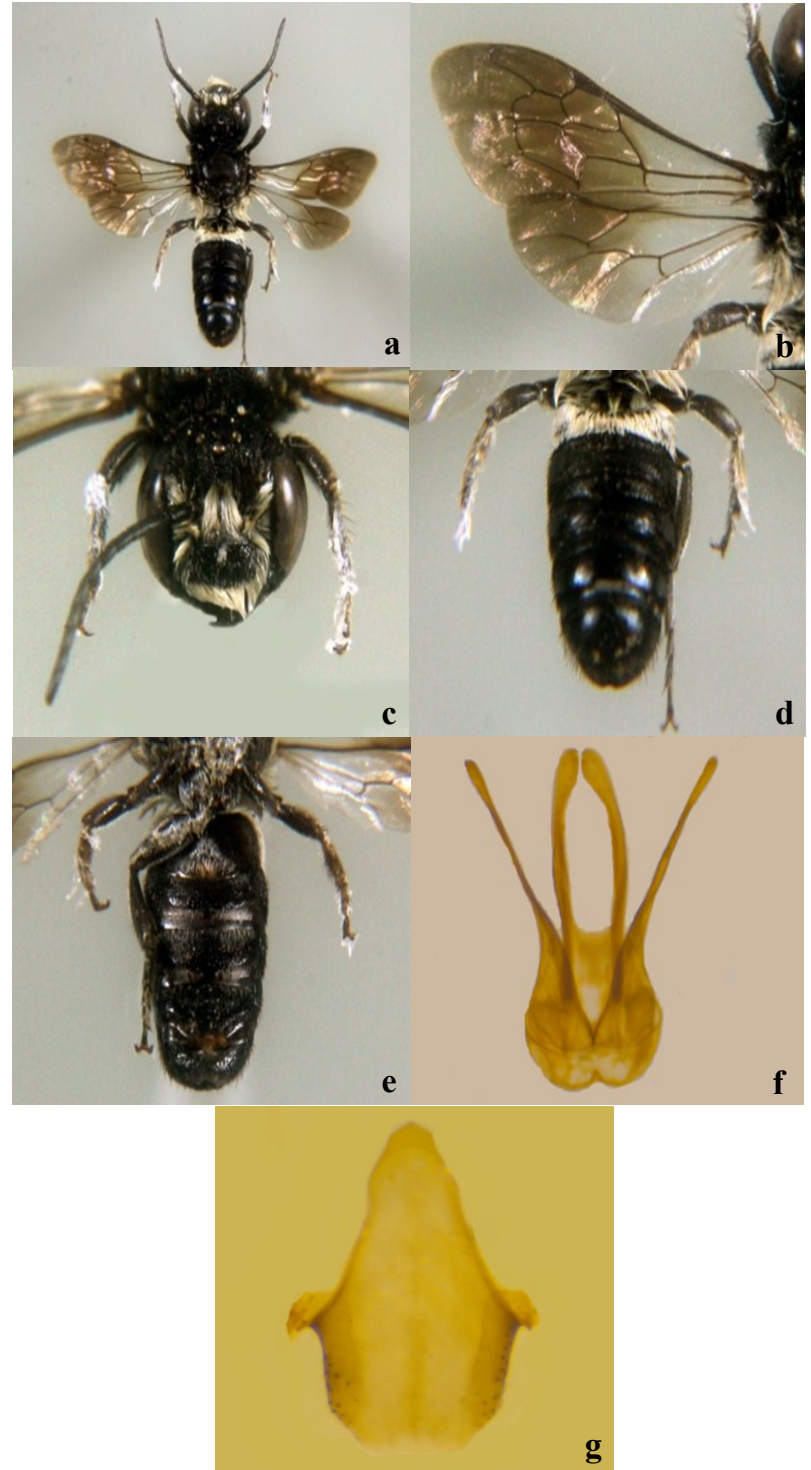

Plate IV (Figs. a-g). Megachile pseudodisjuncta sp. n. male (a.) Habitus, dorsal view (b.) Head and Mesosoma, dorsal view (c.) Wing (d.) Metasoma, dorsal view (e.) Sterna, ventral view (f.) Genitalia (g.) Sternum 8.

disjuncta gonocoxites are thick at the base and narrows at the apex (Plate II, Fig. f). Gonostylii is rounded in M. pseudodisjuncta and blunt in M. disjuncta. Gonobase is narrow in $M$. pseudodisjuncta as compared to $M$. disjuncta.

Zoogeographic record: Chandigarh $\left(30^{\circ} 44^{\prime} 29.3352^{\prime \prime}\right.$ N, 76 46' 5.0376" E), Panchkula (30 41' 42.7272" N, $76^{\circ} 51^{\prime} 15.0192^{\prime \prime}$ E), Kurukshetra (29 58' 10.2468" N, $\left.76^{\circ} 52^{\prime} 41.8116^{\prime \prime} \mathrm{E}\right)$.

Specimen examined: $3 \hat{\jmath}, 12$ March 2014, 4 , 22 March 2014, 3 + 28 March 2014, 1ð, 11 April 2014,

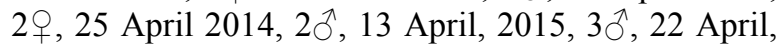
2015.

Floral associations- Fabaceae: Cajanus pallida (L.), Crotalaria juncea (L.) (Fig. 1a and b)

Specimen examined- $3 \hat{\jmath}$, Chandigarh, 12 March 
2013, 4 \&, Panchkula, 22 March 2014, 3 Panchkula, 28 March 2014, 1§ึ, Kurukshetra, 11 April 2014, 2ㅇ, Chandigarh, 25 April 2014, 2خ, Panchkula, 13 April, 2015, 3ึ, Chandigarh, 22 April, 2015.

\section{Conclusion}

This work bears a lot of importance in documenting a new species of this economically important group. Spatio-temporal data, floral associations and measurements of $M$. pseudodisjuncta sp. $\mathrm{n}$. has been provided which is critical for systematics, taxonomy and conservation of biodiversity.

\section{ACKNOWLEDGEMENTS}

Author is thankful to UGC-BSR meritorious fellowship for funding this research work.

\section{REFERENCES}

Bingham, C. T. (1897). Hymenoptera, Vol. I, Wasps and Bees. In W.T. Blanforded. The fauna of British India, Taylor and Francis (London CCIC), pp. 410-579.

Gupta, R. K. (1999). Taxonomic studies on the Megachilidae of North Western India, Scientific Publisher (India), pp. 294.

Kumari, P. and Kumar, N. R. (2014). Studies on Megachile Latreille subgenus Callomegachile Michener (Hymenoptera: Megachilidae) from Chandigarh and Haryana plains, India, Zootaxa. 3814 (4): 591-599.

Michener, C. D. (1962). Observations on the classification of the Bees commonly placed in the genus New York Entomol. Soc. 70:17-29.

Michener, C. D. (2000). The Bees of the World ( $1^{\text {st }}$ Edition), The Johns Hopkins University Press (Baltimore, USA,), pp. 913.

Michener, C. D. (2007). The Bees of the World ( ${ }^{\text {st }}$ Edition), The Johns Hopkins University Press (Baltimore, USA), pp. 953. 